\title{
Feeding behaviour and non-linear responses in dilution experiments in a coastal upwelling system
}

\author{
I. G. Teixeira* ${ }^{*}$ F. G. Figueiras \\ Instituto de Investigacións Mariñas (CSIC), Eduardo Cabello 6, 36208 Vigo, Spain
}

\begin{abstract}
The occurrence of non-linear responses in several dilution experiments conducted in the coastal upwelling system of the Ría de Vigo, Spain, was examined in relation to the possible violation of the basic assumptions of the technique. In addition to linear responses, 2 types of non-linear responses (saturated and saturated-increased responses) were obtained. Saturated responses are those showing constant net growth rates at lower dilutions, while saturated-increased responses depict the increase of net growth rates in low-diluted bottles. Evidence relating these 2 non-linear responses to nutrient limitation or changes in the microzooplankton community was not definitive. In contrast, saturated and saturated-increased responses were frequent when the percentage of microzooplankton was relatively low within a very abundant and diverse plankton community. We suggest that saturated feeding responses were related to the achievement of a maximum ingestion rate by microzooplankton and that saturated-increased responses were associated with selective feeding by microzooplankton at times when microzooplankton was feeding at its maximum ingestion rate. Simulated dilution experiments incorporating these 2 assumptions, 2 consumers and 3 prey were able to reproduce the 3 types of responses. The results indicate that non-linear responses in dilution experiments must be expected in regions with high and diverse food abundance, which should allow prey selection by microzooplankton.
\end{abstract}

KEY WORDS: Non-linear feeding responses $\cdot$ Dilution technique $\cdot$ Microzooplankton $\cdot$ Plankton community $\cdot$ Upwelling systems

\section{INTRODUCTION}

Since its introduction by Landry \& Hassett (1982), the dilution technique, later adapted to accommodate conditions of nutrient limitation (e.g. Andersen et al. 1991, Landry 1993, 1994), has extensively been used to estimate the impact of nano- and microzooplankton (hereafter microzooplankton) on phytoplankton (Calbet \& Landry 2004) and bacteria (e.g. Landry et al. 1984, Tremaine \& Mills 1987, Worden \& Binder 2003) in a wide variety of marine ecosystems. This technique, in which a seawater sample is diluted at several levels with filtered seawater from the same location to reduce the encounter rate of microzooplankton with their prey, relies on 3 fundamental assumptions regarding interactions among nutrients, phytoplankton and microzooplankton (Landry \& Hassett 1982).
(1) It is assumed that phytoplankton grows exponentially. (2) The growth of a given individual phytoplankton is independent of the presence of other phytoplankton individuals and is not nutrient limited. This means that the specific phytoplankton growth rate does not differ between dilution treatments. (3) The probability of a phytoplankton cell being grazed is directly related to its encounter rate with microzooplankton, which implies that the number of cells ingested by a given microzooplankton organism is linearly related to prey density. When these requirements are met, a negative linear relationship between the net growth rate of phytoplankton $\left(k, \mathrm{~d}^{-1}\right)$ and the fraction of unfiltered seawater $(X)$ is obtained, with the slope representing the mortality rate of phytoplankton due to microzooplankton grazing $\left(m, \mathrm{~d}^{-1}\right)$ and the $y$-axis intercept providing an estimate of the 
phytoplankton growth rate in the absence of predators $\left(\mu, d^{-1}\right)$ :

$$
k=\mu-m X
$$

However, non-linear relationships are frequently reported (e.g. Gallegos 1989, Dolan et al. 2000, Strom et al. 2001), with saturated feeding responses, i.e. those showing constant net growth rates at low dilutions, being common in eutrophic systems. On some occasions, these types of non-linear relationships have been attributed to changes in the individual feeding impact of microzooplankton in response to variations in food availability along the dilution series (Gallegos 1989, Moigis 2006). Nevertheless, changes in feeding impact can also be due to variations in the microzooplankton community (Dolan et al. 2000, Dolan \& McKeon 2004, Agis et al. 2007). Thus, changes in growth and mortality of the several microzooplankton species during incubation can induce nonlinearities in their total and/or relative abundance within the dilution series and, consequently, modify their feeding impact. In fact, microzooplankton dynamics during incubation have been cited as a major criticism of the dilution technique, because it would cause mortality patterns of phytoplankton quite different from those occurring in natural communities (Dolan \& McKeon 2004).

Here we present the results of 8 dilution experiments performed in a coastal upwelling system in which linear and non-linear responses were obtained. The main purpose was to investigate the causes for the occurrence of non-linear responses, taking into account the possible violation of the assumptions on which the dilution technique relies. Understanding the mechanisms behind the appearance of non-linear feeding responses in dilution experiments is crucial to accept or reject this methodology as a useful tool to estimate the microzooplankton impact in aquatic systems.

\section{MATERIALS AND METHODS}

Experimental setup. Net growth rates of plankton components $\leq 200 \mu \mathrm{m}$ in the coastal upwelling system of the Ría de Vigo (NW Iberia) were estimated using the dilution technique (Landry \& Hassett 1982). In total, 8 experiments were conducted in February, April, July and September 2002, i.e. 2 each month. All experimental containers, bottles, filters and tubing were soaked in $10 \% \mathrm{HCl}$ and rinsed with Milli-Q water before each experiment. Sampling took place at dawn at a station situated in the main channel at the central part of the Ría de Vigo (Fig. 1) with a 301 Niskin bottle that was dipped twice at the surface. Water from the first dip was gravity filtered through a $0.2 \mu \mathrm{m} \mathrm{Gel-}$

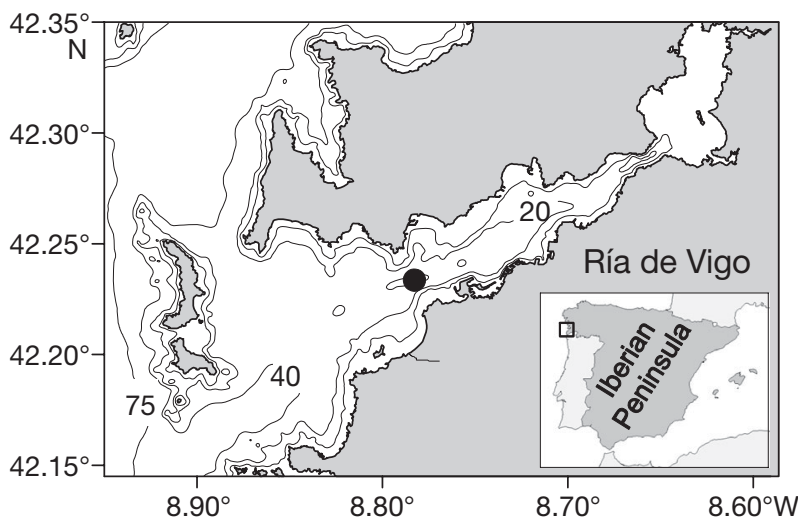

Fig. 1. Ría de Vigo, with the location of the sampled station

man Suporcap filter. Although cell breakage during filtration may increase the concentration of dissolved organic matter (DOM) and inorganic nutrients, we did not observe significant differences between filtered and raw seawater either in dissolved organic carbon or dissolved inorganic nitrogen ( $t$-test for paired samples $p=0.94$ and 0.32 , respectively) using this filtration system. Measured volumes of filtered water and unfiltered seawater obtained from the second dip were gently combined into carboys to obtain dilution levels of $\sim 10,20,40,60,80$ and $100 \%$ of unfiltered seawater. The dilution levels were checked from chlorophyll (chl) a concentrations determined in triplicate samples. Two clear polycarbonate bottles of 2.31 were then completely filled from each dilution level and incubated for $24 \mathrm{~h}$ at simulated in situ light and temperature conditions. Carbon biomass $\left(\mathrm{mg} \mathrm{C} \mathrm{m}^{-3}\right)$ of autotrophic and heterotrophic pico- $(\leq 2 \mu \mathrm{m})$, nano- $(2$ to $20 \mu \mathrm{m})$ and microplankton (20 to $200 \mu \mathrm{m}$ ) were determined in the initial unfiltered seawater and in all experimental bottles after incubation. The initial concentrations for each dilution were estimated taking into account the dilution factor. Chl a was also determined in all bottles after incubation.

Analyses. Chl a was determined by fluorometry after filtering subsamples of $250 \mathrm{ml}$ through $25 \mathrm{~mm}$ Whatman GF/F filters. The filters were then stored frozen at $-20^{\circ} \mathrm{C}$ until pigments were extracted in $90 \%$ acetone at $4^{\circ} \mathrm{C}$ in the dark over $24 \mathrm{~h}$.

Pico- and nanoplankton were determined in subsamples of $10 \mathrm{ml}$ fixed with buffered $0.2 \mu \mathrm{m}$ filtered formaldehyde ( $2 \%$ final concentration) and stained with DAPI at $0.1 \mathrm{\mu g} \mathrm{ml}^{-1}$ final concentration (Porter \& Feig 1980). After $10 \mathrm{~min}$ in the dark, samples were filtered through $0.2 \mu \mathrm{m}$ black Millipore-Isopore filters. The filters were then immersed in low fluorescence immersion oil and examined at 1000x magnification using an epifluorescence microscope. Autotrophic organisms were enumerated under blue light excitation, and heterotrophic organisms were counted under 
excitation with UV light. Prochlorococcus cannot be accurately counted with this technique, but their abundance is not important in this coastal system (Rodríguez et al. 2003). Bacterial biomass was estimated according to Lee \& Fuhrmann (1987). Dimensions of several individuals of the other groups were taken and cell volumes were calculated assuming a spherical shape. Cell carbon was estimated following Verity et al. (1992) for pico- and nanoflagellates and Bratbak \& Dundas (1984) for Synechococcus-type cyanobacteria.

Microplankton was determined in subsamples of 250 to $500 \mathrm{ml}$ preserved in Lugol's iodine. Depending on chl a concentration, a variable volume of 10 to $100 \mathrm{ml}$ was sedimented in composite sedimentation chambers and observed through an inverted microscope. When needed, due to low abundances, additional volumes were sedimented. The organisms were counted and identified to the species level when possible. Phototrophic and heterotrophic species of dinoflagellates were differentiated following Lessard \& Swift (1986) and also using epifluorescence microscopy. Dimensions were taken to calculate cell biovolumes after approximation to the nearest geometrical shape (Hillebrand et al. 1999), and cell carbon was calculated following Strathmann (1967) for diatoms and dinofla- gellates, Verity et al. (1992) for flagellates and Putt \& Stoecker (1989) for ciliates.

Net growth rates $k\left(\mathrm{~d}^{-1}\right)$ were estimated as:

$$
k=\frac{1}{t} \ln \left(\frac{C_{t}}{C_{0}}\right)
$$

where $t$ is the duration of the experiment $(1 \mathrm{~d})$ and $C_{0}$ and $C_{t}$ are the initial and final chl a concentration or carbon biomass, respectively.

\section{RESULTS AND DISCUSSION}

\section{Feeding responses}

Three types of feeding responses were found for total autotrophic (AC), total heterotrophic (HC) plankton $\leq 200 \mu \mathrm{m}$, chl $a$ and the several plankton groups considered (Figs. $2 \& 3$, Tables $1 \& 2$ ). In addition to linear (Fig. 2a-c) and saturated feeding responses (Fig. 2d-f), a third type of response (Fig. $2 \mathrm{~g}-\mathrm{i}$ ) in which the net growth rates increased in the low-diluted bottles (hereafter named saturated-increased response) was also obtained. To our knowledge, this third type of response has only been reported by Gallegos (1989)
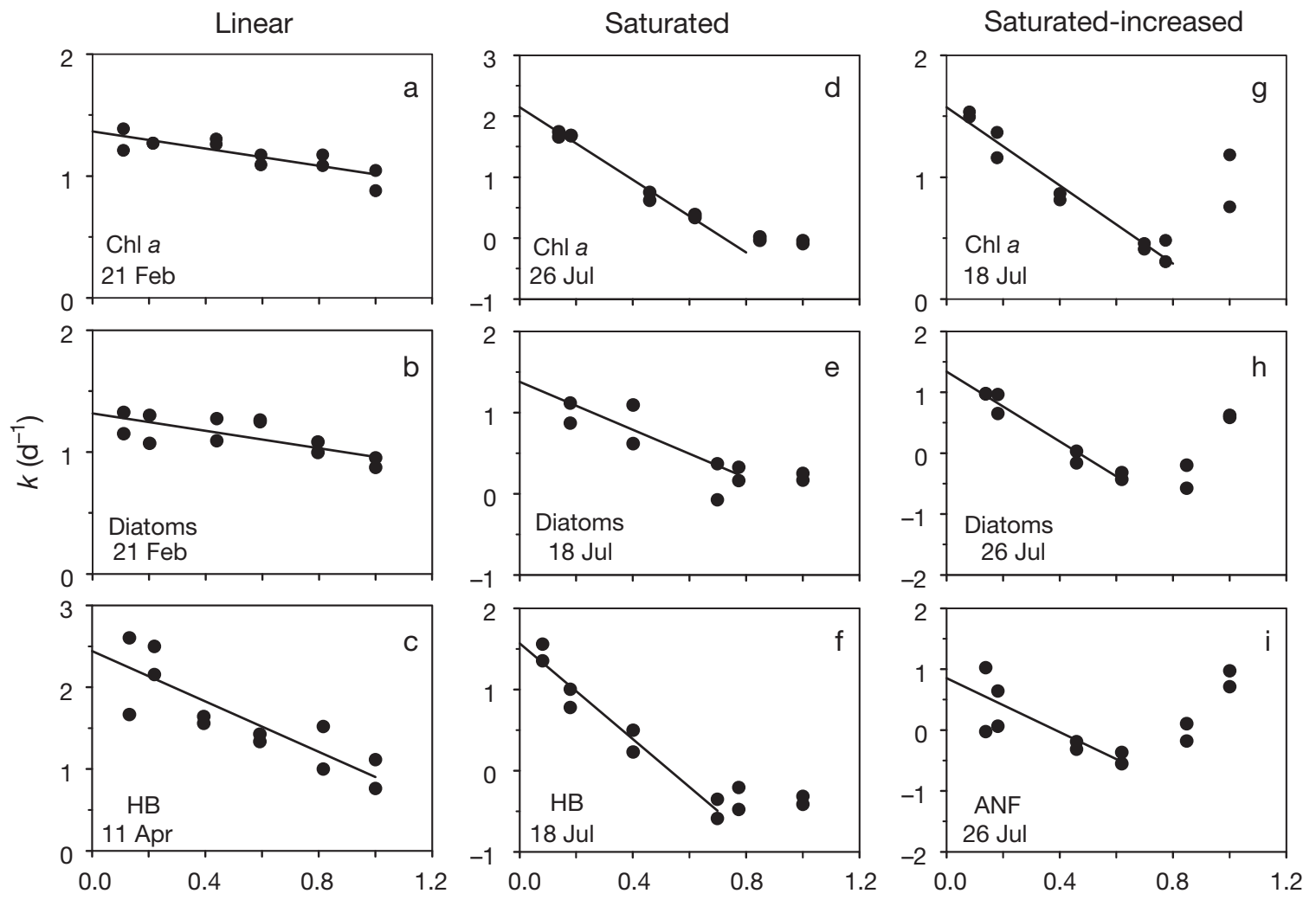

Fraction of unfiltered seawater

Fig. 2. Examples of the 3 types of responses obtained in 8 dilution experiments, Ría de Vigo. (a-c) Linear; (d-f) saturated; (g-i) saturated-increased responses. $k$ : net growth rate of phytoplankton; HB: heterotrophic bacteria; ANF: autotrophic nanoflagellates 

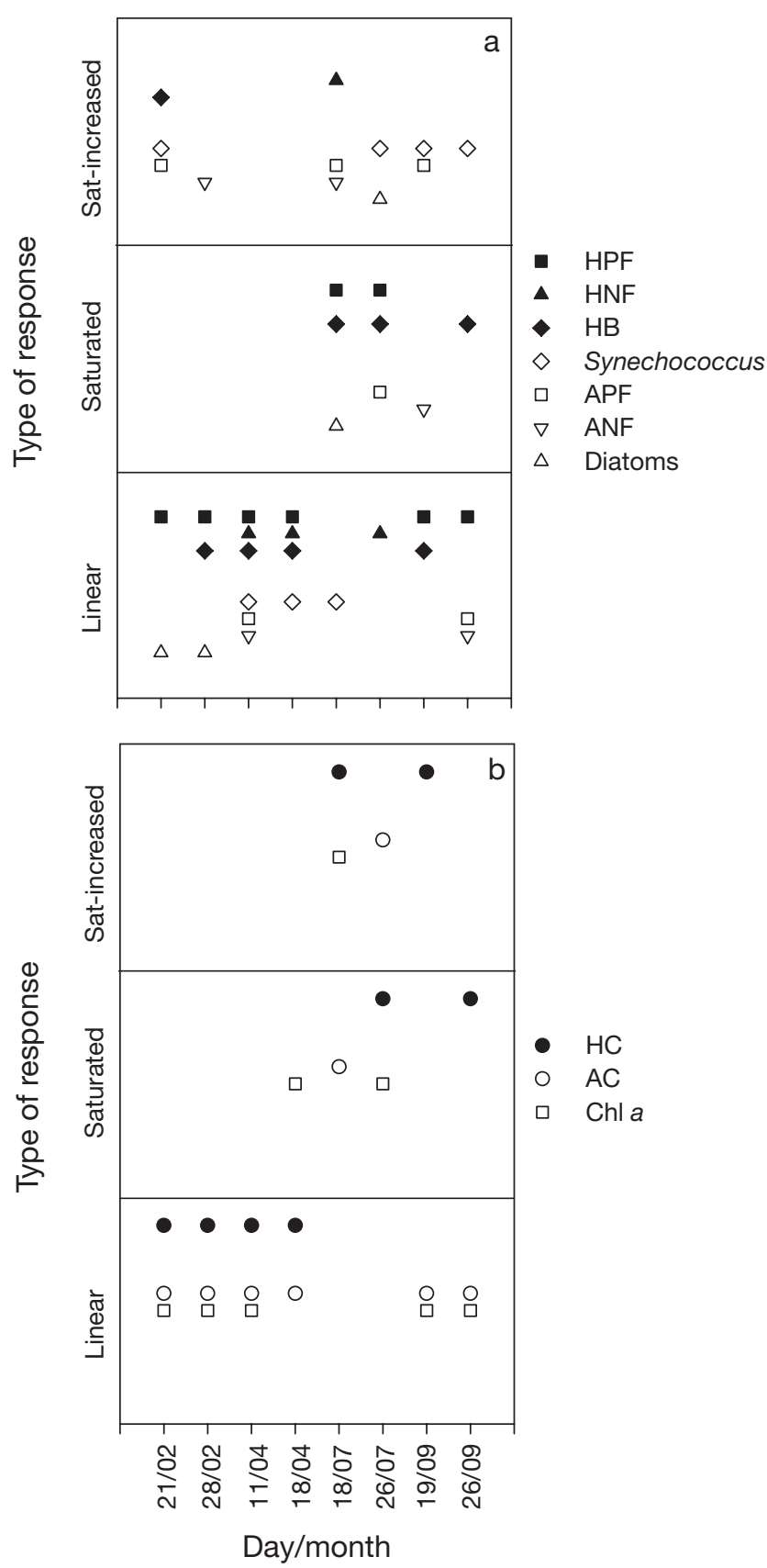

Fig. 3. Distribution of the 3 types of responses found in 8 dilution experiments for (a) plankton groups and (b) bulk plankton properties. ANF: autotrophic nanoflagellates; APF: autotrophic picoflagellates; HNF: heterotrophic nanoflagellates; HPF: heterotrophic picoflagellates; HB: heterotrophic bacteria; AC: total autotrophic carbon; HC: total heterotrophic carbon. The $y$-axis is dimensionless

and Elser \& Frees (1995). Linear relationships were common in February and April, and saturated or saturated-increased responses were more frequent in July (Fig. 3). September did not show a clear dominance of any of the 3 types of responses.
According to the architecture of the dilution technique (Landry \& Hassett 1982), negative linear relationships between the net growth rate and the fraction of unfiltered seawater occur when the specific growth rate keeps constant at all dilution levels and the mortality increases proportionally to the increase in food abundance (represented by the fraction of unfiltered seawater in Eq. 1). Therefore, deviations from linearity mean that any of these 2 conditions are not accomplished: i.e. (1) the specific growth rate differs between dilution treatments and/or (2) mortality rate is not linearly related to prey concentration. In the following sections, the occurrence of non-linear responses will be examined in relation to possible variations in these 2 rates.

\section{Changes in the specific growth rate}

As all bottles were incubated under the same conditions during each particular experiment, the influence of physical variables prone to affect growth rates, such as light and temperature, should have been similar in all incubation bottles. In contrast, changes in concentrations of some chemical components within the dilution bottles could occur. Among all chemicals, nutrients are a main concern in these experiments, since differences in nutrient concentrations along the dilution series can induce changes in phytoplankton growth rates, whenever phytoplankton is nutrientlimited (Andersen et al. 1991, Ayukai 1996, Gaul et al. 1999). Thus, high concentrations of regenerated nutrients in low-diluted bottles can result from increased microzooplankton activity due to high food abundance, and this can enhance phytoplankton specific growth rates. In contrast, highest-diluted bottles would contain lower concentrations of regenerated nutrients, since microzooplankton consumption should be less important. This increase in the specific growth rates in the low-diluted bottles would result in the increment of net growth rates and so lead to the appearance of nonlinear feeding responses.

To avoid the effect of nutrient limitation, it has been proposed to add nutrients to all incubation bottles well in excess for phytoplankton growth (Landry \& Hassett 1982, Andersen et al. 1991, Landry 1994). However, the consequences of this experimental step are controversial, because it can cause losses of oligotrichous ciliates (Gifford 1988) and may also affect phytoplankton growth negatively (Lessard \& Murrell 1998, Worden \& Binder 2003). Moreover, changes in microzooplankton behaviour and in the shape of the functional response have also been reported when nutrients were added (Worden \& Binder 2003). Owing to these uncertainties and with the aim of maintaining the plankton commu- 
Table 1. Growth $\left(\mu, \mathrm{d}^{-1}\right)$ and mortality $\left(m, \mathrm{~d}^{-1}\right)$ rates obtained from dilution experiments for autotrophic plankton. APF: autotrophic picoflagellates; ANF: autotrophic nanoflagellates; AC: total autotrophic carbon; chl a: chlorophyll $a$; ns: not significant. For saturated and saturated-increased responses, $r^{2}$ and $\mu$ were obtained by regression of the linear part of the responses, and $m$ was estimated as the difference between $\mu$ and the net growth rate $(k)$ in the undiluted sample. See text and Fig. 6 for more details. $\mathrm{p}<0.05$ for linear responses. The significance of saturated and saturated-increased responses was on some occasions $>0.05$ owing to the few points included in the regression

\begin{tabular}{|c|c|c|c|c|c|c|c|c|c|c|c|c|c|c|c|c|c|c|}
\hline \multirow{2}{*}{ Date } & \multicolumn{3}{|c|}{ Synechococcus } & \multirow[b]{2}{*}{$m$} & - APF & \multirow[b]{2}{*}{$\mathrm{r}^{2}$} & \multirow[b]{2}{*}{$m$} & \multirow{2}{*}{$\begin{array}{c}\text { ANF } \\
\mu\end{array}$} & \multirow[b]{2}{*}{$\mathrm{r}^{2}$} & \multicolumn{2}{|c|}{ — Diatoms } & \multirow{2}{*}{$\mathrm{s}-\overline{\mathrm{r}^{2}}$} & \multirow[b]{2}{*}{$m$} & \multirow{2}{*}{$\begin{array}{c}\mathrm{AC} \\
\mu\end{array}$} & \multirow[b]{2}{*}{$\mathrm{r}^{2}$} & \multirow[b]{2}{*}{$m$} & \multirow{2}{*}{$\begin{array}{c}\operatorname{chl} a \\
\mu\end{array}$} & \multirow[b]{2}{*}{$\mathrm{r}^{2}$} \\
\hline & $m$ & $\mu$ & $\mathrm{r}^{2}$ & & $\mu$ & & & & & $m$ & $\mu$ & & & & & & & \\
\hline 21 Feb & 0.11 & 0.56 & $0.95^{\mathrm{b}}$ & 0.70 & 1.47 & $0.96^{\mathrm{b}}$ & ns & ns & ns & 0.36 & 1.32 & 0.68 & 0.35 & 1.27 & 0.77 & 0.35 & 1.36 & 0.87 \\
\hline 28 Feb & $\mathrm{ns}$ & ns & ns & ns & ns & ns & 0.75 & 1.03 & $0.78^{\mathrm{b}}$ & 0.10 & 0.70 & 0.93 & 0.21 & 0.73 & 0.81 & 0.23 & 0.72 & 0.69 \\
\hline 11 Apr & 1.18 & 2.08 & 0.81 & 1.58 & 0.73 & 0.97 & 0.85 & 0.37 & 0.89 & ns & ns & ns & 0.77 & 0.42 & 0.93 & 0.61 & 0.07 & 0.81 \\
\hline 18 Apr & 0.39 & 0.31 & 0.95 & ns & ns & ns & ns & ns & ns & ns & ns & ns & 0.39 & 0.31 & 0.95 & 0.56 & 0.09 & $0.99^{\mathrm{a}}$ \\
\hline $18 \mathrm{Jul}$ & 0.88 & 1.13 & 0.94 & 1.39 & 1.39 & $0.98^{\mathrm{b}}$ & 0.33 & 1.46 & $0.99^{b}$ & 1.13 & 1.33 & $0.92^{\mathrm{a}}$ & 1.10 & 1.33 & $0.92^{\mathrm{a}}$ & 0.58 & 1.57 & $0.98^{\mathrm{b}}$ \\
\hline $26 \mathrm{Jul}$ & 0.28 & 1.63 & $0.89^{\mathrm{b}}$ & 2.55 & 2.86 & $0.99^{\mathrm{a}}$ & 0.0 & 0.85 & $0.97^{\mathrm{b}}$ & 0.73 & 1.33 & $0.99^{\mathrm{b}}$ & 0.74 & 1.35 & $0.99^{b}$ & 2.22 & 2.15 & $0.99^{\mathrm{a}}$ \\
\hline 19 Sep & 0.24 & 0.75 & $0.92^{\mathrm{b}}$ & 1.27 & 3.14 & $0.97^{b}$ & 0.79 & 0.86 & $0.99^{\mathrm{a}}$ & ns & ns & ns & 0.49 & 0.87 & 0.77 & 0.24 & 0.37 & 0.87 \\
\hline 26 Sep & 1.09 & 1.78 & $0.99^{b}$ & 1.76 & 3.04 & 0.91 & 0.32 & 1.49 & 0.89 & ns & ns & ns & 0.58 & 1.75 & 0.70 & 0.25 & 1.31 & 0.73 \\
\hline
\end{tabular}

Table 2. As in Table 1, but for heterotrophic plankton. HB: heterotrophic bacteria; HPF: heterotrophic picoflagellates; HNF: heterotrophic nanoflagellates; HC: total heterotrophic carbon; ns: not significant

\begin{tabular}{|c|c|c|c|c|c|c|c|c|c|c|c|c|}
\hline \multirow{2}{*}{ Date } & \multicolumn{3}{|c|}{ HB } & \multicolumn{3}{|c|}{$\mathrm{HPF}$} & \multicolumn{3}{|c|}{$\mathrm{HNF}$} & \multicolumn{2}{|r|}{$\mathrm{HC}$} & \multirow[b]{2}{*}{$\mathrm{r}^{2}$} \\
\hline & $m$ & $\mu$ & $r^{2}$ & $m$ & $\mu$ & $r^{2}$ & $m$ & $\mu$ & $r^{2}$ & $m$ & $\mu$ & \\
\hline 21 Feb & 0.94 & 1.42 & $0.97^{\mathrm{b}}$ & 2.66 & 2.24 & 0.97 & ns & ns & ns & 0.88 & 0.73 & 0.74 \\
\hline 28 Feb & 1.31 & 2.24 & 0.92 & 1.41 & 1.25 & 0.66 & ns & ns & ns & 1.05 & 1.57 & 0.87 \\
\hline 11 Apr & 1.54 & 2.44 & 0.90 & 1.27 & 1.97 & 0.87 & 0.87 & 0.74 & 0.86 & 0.79 & 1.06 & 0.99 \\
\hline 18 Apr & 1.48 & 1.24 & 0.96 & 2.00 & 1.78 & 0.88 & 0.63 & 0.11 & 0.98 & 0.99 & 0.48 & 0.95 \\
\hline $18 \mathrm{Jul}$ & 1.92 & 1.56 & $0.98^{\mathrm{a}}$ & 1.99 & 1.98 & $0.98^{\mathrm{a}}$ & 0.22 & 1.58 & $0.68^{b}$ & 0.81 & 1.40 & $0.96^{\mathrm{b}}$ \\
\hline $26 \mathrm{Jul}$ & 1.68 & 2.25 & $0.96^{\mathrm{a}}$ & 1.70 & 2.70 & $0.96^{\mathrm{a}}$ & 1.12 & 1.81 & 0.74 & 1.27 & 1.82 & $0.90^{\mathrm{a}}$ \\
\hline 19 Sep & 1.82 & 2.01 & 0.99 & 1.88 & 1.39 & 0.90 & ns & ns & ns & 0.63 & 0.62 & 0.93 \\
\hline 26 Sep & 0.97 & 1.14 & $0.92^{\mathrm{a}}$ & 2.15 & 1.95 & 0.91 & ns & ns & ns & 0.46 & 0.80 & 0.81 \\
\hline
\end{tabular}

Table 3. Initial conditions for each experiment. DIN: dissolved inorganic nitrogen; TC: total carbon of the plankton community; Microzoo \%: percentage of microzooplankton biomass in the plankton community

\begin{tabular}{|lccccccc|}
\hline Date & $\begin{array}{c}\text { Salinity } \\
(\mathrm{psu})\end{array}$ & $\begin{array}{c}\text { Temperature } \\
\left({ }^{\circ} \mathrm{C}\right)\end{array}$ & $\begin{array}{c}\mathrm{DIN} \\
\left(\mu \mathrm{mol} \mathrm{l}^{-1}\right)\end{array}$ & $\begin{array}{c}\mathrm{HPO}_{4}{ }^{2-} \\
\left(\mu \mathrm{mol} \mathrm{l}^{-1}\right)\end{array}\left(\mathrm{mg} \mathrm{m}^{-3}\right)\left(\mathrm{mg} \mathrm{m}^{-3}\right)$ & $\begin{array}{c}\text { Microzoo } \\
(\%)\end{array}$ \\
\hline 21 Feb & 35.5 & 13.2 & 5.41 & 0.41 & 3.3 & 200 & 25 \\
$28 \mathrm{Feb}$ & 35.4 & 13.2 & 4.38 & 0.34 & 2.7 & 84 & 19 \\
$11 \mathrm{Apr}$ & 34.6 & 13.4 & 0.20 & 0.17 & 4.2 & 143 & 27 \\
18 Apr & 35.3 & 13.8 & 0.68 & 0.18 & 6.2 & 341 & 37 \\
18 Jul & 35.2 & 15.3 & 1.38 & 0.37 & 6.7 & 819 & 7 \\
26 Jul & 35.3 & 16.6 & 3.51 & 0.51 & 5.8 & 333 & 10 \\
19 Sep & 34.8 & 16.9 & 2.13 & 0.31 & 5.3 & 407 & 29 \\
26 Sep & 35.0 & 17.8 & 3.66 & 0.41 & 3.4 & 460 & 19 \\
\hline
\end{tabular}

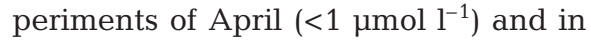
the experiment of $18 \mathrm{July}\left(1.38 \mu \mathrm{mol}^{-1}\right)$. Initial concentrations of phosphate were also significantly lower $(\mathrm{p}<0.05)$ in both experiments of April and in the experiment of 19 September. If nutrient limitation was responsible for the appearance of non-linear responses, a higher frequency of saturated and saturated-increased responses should be expected under the most limiting conditions of April. However, responses in April were linear, whereas saturated and saturated-increased responses were more frequent in July (Fig. 3). On 19 September, all 3 responses were observed (Fig. 3). Saturated and saturatedincreased responses were also obtained for heterotrophic plankton organisms in July (Fig. 3), and although heterotrophs can compete with phytoplankton for inorganic nutrients (e.g. Wheeler \& Kirchman 1986), their specific growth rates should be less affected. Therefore, nity as close as possible to in situ conditions, we did not add nutrients to our incubation bottles. Consequently, this could have caused the appearance of non-linear responses in our dilution experiments.

Initial nutrient concentrations (Table 3) were in some cases extremely low. Total inorganic nitrogen was significantly lower ( $p<0.01, t$-test for 2 samples) in the 2 ex- 
we can cautiously conclude that nutrient limitation was not the main factor causing saturated and saturatedincreased response in our experiments, although nutrient influence was not specifically assessed.

\section{Changes in the mortality rate}

The mortality rate at each dilution level $\left(m_{X}, \mathrm{~d}^{-1}\right)$ is a function of microzooplankton clearance rate $(C, \mu \mathrm{pg}$ $\left.\mathrm{C}^{-1} \mathrm{~d}^{-1}\right)$ and microzooplankton abundance $\left(Z_{X}\right.$, pg $C$ $\mu^{-1}$ ) (Landry \& Hassett 1982, Gallegos 1989):

$$
m_{X}=c Z_{X}
$$

For the case of linear relationships, it is assumed that microzooplankton ingests prey at its maximum clearance rate. Therefore, the mortality rate along a dilution series should increase according to the increase in microzooplankton abundance, which in turn is proportional to the fraction of unfiltered seawater. Consequently, any change in the proportionality of the mortality rate $\left(m_{X}\right)$ in a dilution experiment must be related to (1) changes in microzooplankton abundance and/or (2) changes in the clearance rate, during the incubation and along the dilution series.

\section{Changes in microzooplankton abundance}

Changes in microzooplankton growth and mortality within the dilution series, which resulted in changes in microzooplankton abundance, have been reported (Dolan et al. 2000, Dolan \& McKeon 2004, Agis et al. 2007). Dolan et al. (2000) observed that net growth rates of oligotrichs and tintinnids increased in the high-diluted bottles following an increase in the abundance of potential nanoplankton prey. In contrast, net growth rates remained constant at the high prey abundance in the lowdiluted bottles, which coincided with saturation in the chl a response. Interestingly, Gallegos (1989) simulated a saturated-increased response assuming higher predation on microzooplankton in low-diluted bottles, and concluded that predation on microzooplankton would release prey from microzooplankton impact allowing them to increase their net growth rates.

Changes in the microzooplankton community also occurred in some of our experiments (Table 4). However, these changes were linear, with microzooplankton increasing (slope $>1$ ) or decreasing (slope $<1$ ) during incubations. For the cases with non-significant regressions $\left(0.37 \leq \mathrm{r}^{2} \leq 0.66\right)$ between ini- tial and final microzooplankton abundance, changes were also linear. There was no case showing a regular decrease at lower dilutions that could be related to the appearance of saturated-increased responses. Moreover, most of the non-significant regressions occurred on 28 February and in the 2 experiments of April, when the responses in dilution experiments were linear (Fig. 3).

According to Eq. (3), linear changes in microzooplankton abundance without variations in the clearance rate during incubation can cause modifications in the slope defining mortality rates, but not in the shape of the response. This can be appreciated comparing the real responses obtained in the experiments to the expected responses assuming that microzooplankton abundance varied linearly while clearance rate was maintained constant. The results show that real and simulated responses were different (Fig. 4). Saturatedincreased responses occurred when microzooplankton biomass did not change during the experiment (Fig. 4a, Table 4), as well as when there was an increase (Fig. 4b) or decrease (Fig. 4c) in the microzooplankton biomass. Consequently, we can conclude that the non-linear responses that we found in our dilution experiments were not apparently related to changes in the microzooplankton community. Instead, they would be attributed to changes in the clearance rate.

\section{Changes in feeding behaviour}

The carbon specific ingestion rate of a given microzooplankton organism ( $I$, pg $C_{\text {prey }}$ pg $C_{\text {microzoo }}{ }^{-1} \mathrm{~d}^{-1}$ ) is a function of the specific clearance rate $\left(c, \mu l \mathrm{pg} \mathrm{C}^{-1} \mathrm{~d}^{-1}\right)$ and prey concentration $\left(P, p g \mathrm{C}^{-1}\right)$ (e.g. Frost 1972, Landry \& Hassett 1982):

$$
I=C P
$$

In linear responses, it is assumed that microzooplankton ingests prey at its maximum clearance rate,

Table 4. Slopes \pm SE of the initial versus final carbon biomass of microzooplankton in the 8 dilution experiments. Microzoo: total microzooplankton, HNF: heterotrophic nanoflagellates, HDF: heterotrophic dinoflagellates. For all significant relationships, the $y$-axis intercept was not significantly different from 0 . ${ }^{*} \mathrm{p}<0.05,{ }^{* *} \mathrm{p}<0.01, \mathrm{~ns}$ : not significant

\begin{tabular}{|lcccc|}
\hline Date & Microzoo & HNF & HDF & Ciliates \\
\hline $21 \mathrm{Feb}$ & $0.93 \pm 0.19^{* *}$ & $0.89 \pm 0.17^{* *}$ & $\mathrm{~ns}$ & $4.15 \pm 0.86^{* *}$ \\
$28 \mathrm{Feb}$ & $\mathrm{ns}$ & $\mathrm{ns}$ & $2.10 \pm 0.60^{*}$ & $5.09 \pm 1.48^{*}$ \\
$11 \mathrm{Apr}$ & $\mathrm{ns}$ & $\mathrm{ns}$ & $1.05 \pm 0.17^{* *}$ & $1.02 \pm 0.29^{*}$ \\
$18 \mathrm{Apr}$ & $\mathrm{ns}$ & $\mathrm{ns}$ & $0.18 \pm 0.03^{* *}$ & $1.11 \pm 0.34^{*}$ \\
18 Jul & $2.06 \pm 0.61^{*}$ & $2.99 \pm 0.91^{*}$ & $1.13 \pm 0.26^{*}$ & $\mathrm{~ns}$ \\
26 Jul & $1.19 \pm 0.19^{* *}$ & $1.50 \pm 0.49^{*}$ & $0.54 \pm 0.06^{* *}$ & $\mathrm{~ns}$ \\
19 Sep & $0.99 \pm 0.11^{* *}$ & $1.63 \pm 0.49^{*}$ & $0.86 \pm 0.10^{* *}$ & $0.73 \pm 0.23^{*}$ \\
26 Sep & $1.41 \pm 0.30^{* *}$ & $2.35 \pm 0.56^{*}$ & $0.56 \pm 0.15^{*}$ & $\mathrm{~ns}$ \\
\hline
\end{tabular}




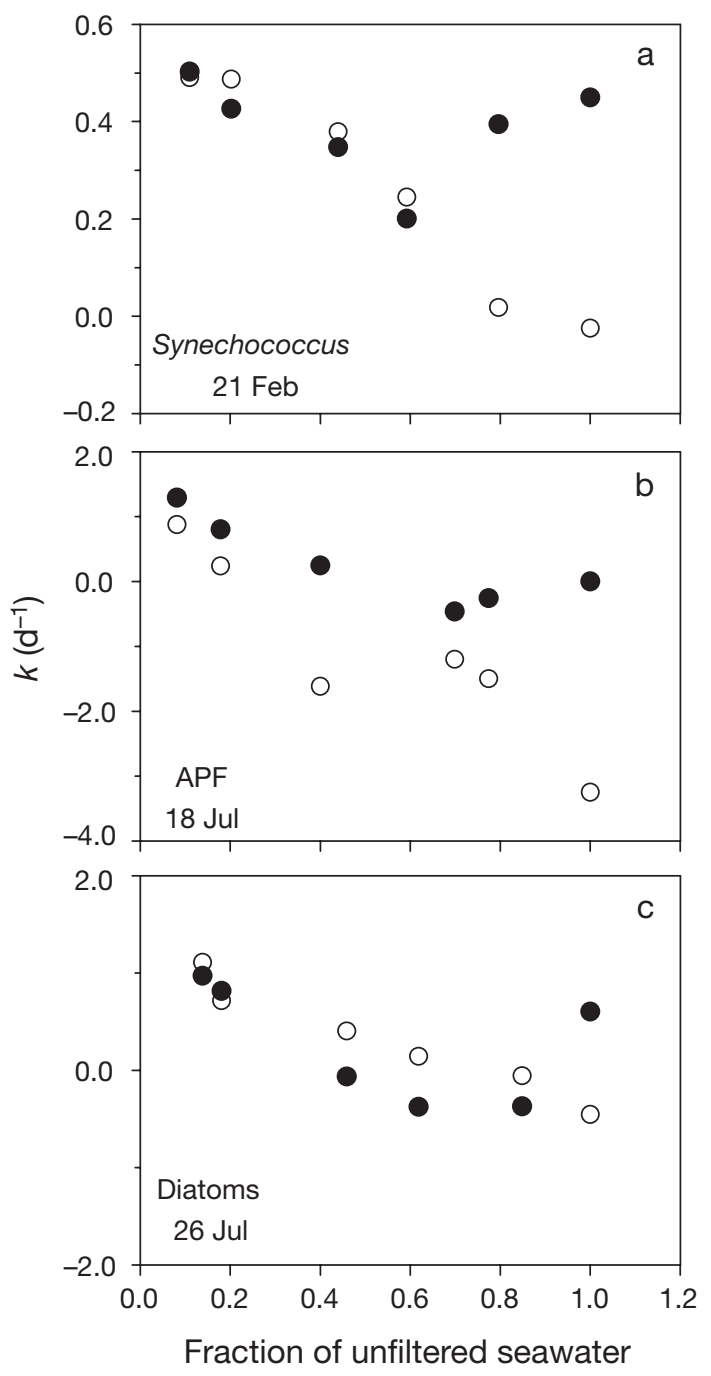

Fig. 4. Real (๑) and simulated $(\mathrm{O})$ responses of 3 dilution experiments. Simulated responses were made with the microzooplankton biomass at the end of the experiments and assuming a constant maximum clearance rate. These maximum clearance rates were estimated, using Eq. (3), from mortality rates observed at the highest dilution levels in real responses. In (a) and (b), simulated responses are for total microzooplankton; in (c), they are for heterotrophic dinoflagellates. Note that the impact of changes in microzooplankton biomass is minimal at the highest dilutions. $k$ : net growth rate of phytoplankton; APF: autotrophic picoflagellates

and thus ingestion rates increase in proportion to the increase in prey abundance, represented by the fraction of unfiltered seawater. However, microzooplankton may reach a maximum ingestion rate at high food concentrations. For example, Heinbokel (1978) showed that the ingestion rate of tintinnids increased up to a maximum value following the availability of prey. The maximum ingestion rate then remained constant despite further increases in prey abundance. In these cases, as food availability increases, there is a proportional decrease in the microzooplankton clearance rate to maintain the ingestion at its maximum constant value (cte).

$$
I \max =\text { cte }=c P
$$

This feeding behaviour is an argument often used to explain the occurrence of saturated feeding responses in dilution experiments (e.g. Gallegos 1989, Moigis 2006). However, the occurrence of saturated-increased responses necessarily implies the decrease in the ingestion rate when food increases, which means that the decrease in the clearance rate should be more abrupt and not proportional to the increase in food availability.

Total carbon biomass in our experiments (Table 3) was significantly higher in July and September than in February and April ( $\mathrm{p}<0.05, t$-test for 2 samples). In July, when only 2 responses were linear (Fig. 2), initial chl a concentrations were also higher $(p<0.05)$ and percentages of microzooplankton biomass were lower $(\mathrm{p}<0.001)$ than in the other experiments (Table 2). From this, we can infer that saturated and saturatedincreased responses were more frequent in the experiments where there was a low percentage of microzooplankton within a very abundant plankton community. The excess of food can saturate the ingestion of microzooplankton and therefore can cause saturated feeding responses. The reasons for the decrease in the ingestion rate that leads to the occurrence of saturated-increased responses are not clear, but we hypothesise that it could result from active or passive food selection by microzooplankton when prey availability is high. Active prey selection is a well documented process, and it has been attributed to several factors, such as morphological characteristics, presence of metabolites or nutritive value of prey (e.g. Verity 1991, Wolfe et al. 1997, John \& Davidson 2001). This selectivity is more important in situations with high food availability (Heinbokel 1978, Jürgens \& DeMott 1995, John \& Davidson 2001), when the concentration of preferred prey is sufficient to satisfy the nutritional needs of the predator. Passive selection could be due to different encounter rates between microzooplankton and its prey, which can release the less abundant prey from predation in situations of high food availability, because the maximum ingestion rate of microzooplankton is satisfied with the more abundant prey. Both types of selection would explain why saturated-increased responses in our dilution experiments were more frequent in July, when food was abundant (Table 3).

This hypothesis on prey selectivity was assessed by simulating 2 dilution experiments. The 2 simulations contained 3 prey (A, B and C) and 2 microzooplankton species (M1 and M2) with initial biomasses $\left(\mathrm{pg} \mathrm{C} \mu \mathrm{l}^{-1}\right)$ proportional to the dilution levels (Prey $\mathrm{A}=30 X$, Prey B 
$=100 X$, Prey $\mathrm{C}=80 X, \mathrm{M} 1=20 X$ and $\mathrm{M} 2=20 X$, where $X$ is the fraction of unfiltered seawater). In the first simulation, the maximum ingestion rate of both M1 and M2

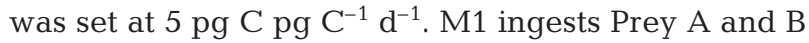
but prefers Prey $\mathrm{A}$, and this preference establishes when its maximum ingestion rate is satisfied. Note that this preference of M1 for the less abundant Prey A can be ascribed to active selection. M2 only ingests Prey C. With these assumptions, the ingestion rates of each prey at each dilution level were calculated with Eq. (4), assuming a maximum clearance rate of $0.11 \mu \mathrm{l} \mathrm{pg} \mathrm{C^{-1 }}$ $\mathrm{d}^{-1}$ for both consumers. Then, once the available food (Prey A + Prey B) in the low-diluted bottles allows M1 to ingest $\geq 5$ pg C pg C ${ }^{-1} \mathrm{~d}^{-1}$, the ingestion of Prey B was calculated as the difference between this maximum ingestion rate and the ingestion calculated for Prey A. This implies that the clearance rate of M1 for Prey B diminishes. With these ingestions calculated for each prey and dilution level, the corresponding clearance rates for each prey and dilution were estimated with Eq. (4). Clearance rates were then used in Eq. (3) to estimate mortality rates at each dilution level, which were used to estimate the net growth rates of each prey as the difference between the specific growth rate $(\mu=$ $0.7 \mathrm{~d}^{-1}$ for the 3 prey) and the mortality rates. In the second simulation, which corresponded to passive selection of the more abundant prey, the maximum ingestion rate of $\mathrm{M} 1$ was set at $10 \mathrm{pg} \mathrm{C} \mathrm{pg} \mathrm{C}^{-1} \mathrm{~d}^{-1}$ with no prey preference. All other parameters and rates were equal to those used in the first simulation.

The outputs of the 2 simulations (Fig. 5) show the 3 types of responses. Feeding on Prey $\mathrm{C}$ was saturated in the 2 cases, because consumption of this prey remained constant after $\mathrm{M} 2$ reached its maximum ingestion rate, despite further increases in food concentration. In contrast, the responses of Prey A and B changed according to the restriction imposed. For the case of active selection (Fig. 5a), the release of pressure on the more abundant Prey B allows it to grow, whereas for the case of passive selection (Fig. 5b) the release of pressure occurs on the less abundant Prey A. The biomass of the other prey (A and B) was not enough to saturate the ingestion rate of M1, and this resulted in linear responses for both.

\section{Some considerations of viral influence}

It must be noted that in the present analysis, the virus influence was not specifically assessed. Regarding the dilution technique, 2 basic concerns can be distinguished. The first refers to the use of water filtered through $0.2 \mu \mathrm{m}$ pores, which is grazer-free but not virusfree. Thus, virus concentration should be equal at all dilution levels, and if viral infection is density dependent,

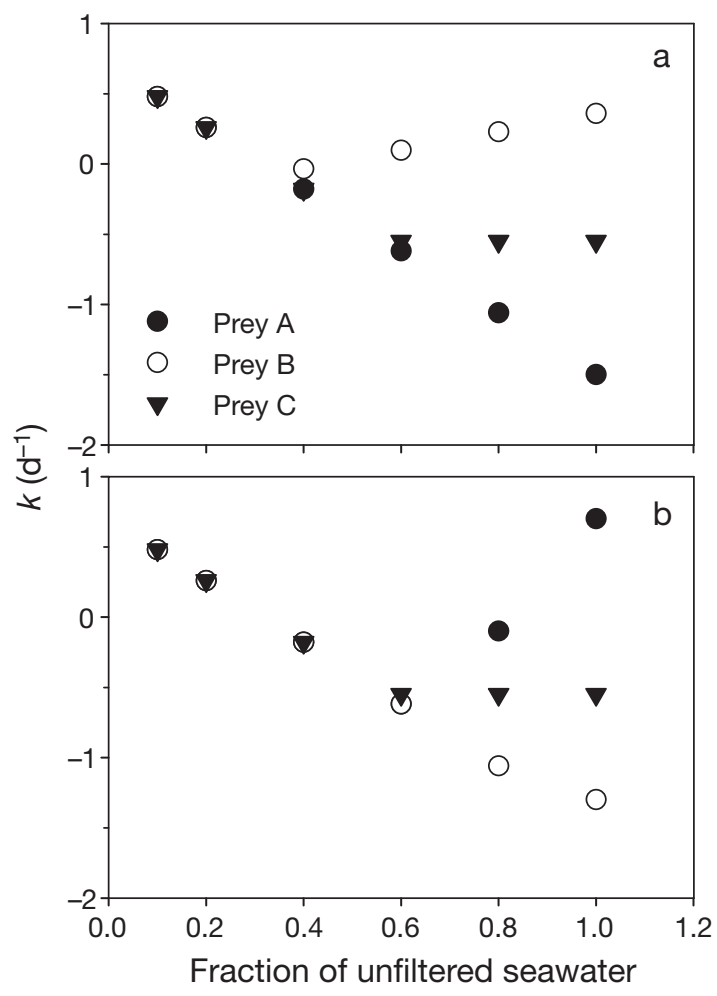

Fig. 5. Output of the simulations made with dilution experiments considering (a) active and (b) passive selection of prey. $k$ : net growth rate of phytoplankton

mortality due to virus should be constant and hence lead to the sub-estimation of specific growth rates (Evans et al. 2003, Baudoux et al. 2006). Although an accurate estimate of rates is the objective of dilution experiments, a constant mortality factor due to virus at all dilution levels should not induce the appearance of non-linear responses. The second concern relates to enhanced viral infection at high grazing activity (Šimek et al. 2001, Sime-Ngando \& Pradeep Ram 2005, Weinbauer et al. 2007), which would lead to higher viral infection in lowdiluted bottles. This can be relevant concerning non-linear responses, because the enhanced virus infection would cause a significant increase in lysis mortality during the incubation time, enhancing nutrient and DOM concentrations in those bottles, and would so affect specific growth rates. To what extent viruses are responsible for the appearance of non-linear responses in dilution experiments is a topic that needs further assessment.

\section{Feeding behaviour in the Ría de Vigo}

While definitive conclusions on the occurrence of food selection cannot be attained from the output of dilution experiments, because incubations are done with all populations interacting at the same time, the different responses obtained (Fig. 3a, Tables 1 \& 2) 
suggest its occurrence in the Ría de Vigo. Non-linear responses were more frequent in summer (July) and at the beginning of autumn (September), when typically upwelling brings nutrients to the system and plankton diversity is high (Figueiras et al. 2002). At that time, several heterotrophic (ciliates, Protoperidinium spp.) and mixotrophic species (Ceratium spp., Dinophysis spp.) of different size coexist with a very abundant and diverse autotrophic community composed of several diatom species and autotrophic nanoflagellates. This situation would be suitable for the appearance of different trophic relationships in which passive or active selection of food could be possible. Winter blooms of diatoms, like that recorded in February (ÁlvarezSalgado et al. 2005), may also be appropriate for this type of relationship (Fig. 3a), because grazing on diatoms can release other prey species from predation. In situations with relatively low abundance of food, such as that in April, selection of food should be less feasible (Fig. 3a). In general, heterotrophic bacteria (HB) and heterotrophic picoflagellates appear to be a suitable food for microzooplankton, because responses (with the exception of HB on 21 February) were linear or saturated (Fig. 3a). In contrast, Synechococcus frequently showed saturated-increased responses, mainly in summer and autumn (Fig. 3a). This suggests that Synechococcus was not a preferred prey, which agrees with previous results reported by other authors. Caron et al. (1991) observed 1 case of active selection against Synechococcus, which, compared to bacteria, was not a good food source for protozoa. The results obtained by Fonda Umani \& Beran (2003) also suggest this type of negative selection on Synechococcus.

Chl $a$ and AC did not always show the same type of response and rates (Fig. 3b, Table 1), which might be attributed to the different carbon:chl a ratios of the several phytoplankton species that then result in different feeding responses for these 2 bulk properties.

\section{CONCLUSIONS}

Although not clearly observed, there is evidence that non-linear feeding responses in this work occurred due to non-linear feeding behaviour of microzooplankton. Furthermore, we suggest that the non-linear feeding behaviour of microzooplankton may be a consequence of the complexity of the microbial food web, where a diverse plankton community can lead to the occurrence of numerous trophic interactions. Microzooplankton can feed on a wide variety of prey, from phytoplankton to bacteria and other heterotrophic organisms (e.g. Rassoulzadegan \& Sheldon 1986, Jeong 1999). Consumers may hence modify their food preference depending on the abundance and quality of prey and so release or hold pressure on some plankton components, producers or consumers, which would cause an increase or decrease in their populations. Moreover, mixotrophic organisms are relatively abundant in plankton communities (Bockstahler \& Coats 1993, Stoecker 1999, Zubkov \& Tarran 2008), and they often regulate their nutrition mode according to food and nutrient accessibility, changing to heterotrophy under conditions of enough food or nutrient limitation (Sanders et al. 1990, Arenovski et al. 1995). Therefore, feeding behaviour should be especially relevant in aquatic systems with high availability and diversity of prey.

Non-linear feeding behaviour of microzooplankton implies the violation of the assumption that the consumption rate is linearly related to the dilution factor. However, this does not invalidate the use of the dilution technique. Non-linear feeding behaviour of microzooplankton is an intrinsic property of these organisms and should also occur in the environment. The main concern with the occurrence of non-linear feeding responses in dilution experiments is the accurate calculation of the rates. If we assume that the net growth rate in the undiluted bottle integrates all growth and mortality processes operating in the environment, the critical point is to obtain accurate estimates of specific growth rates in the absence of predators. In our experiments, the specific growth rates calculated as the $y$-axis intercept of the regression of the linear part of the non-linear responses (Strom et al. 2001, Moigis 2006) do not differ from the specific growth rates estimated from simulated responses as in Fig. 4, that is, using final microzooplankton biomasses and assuming

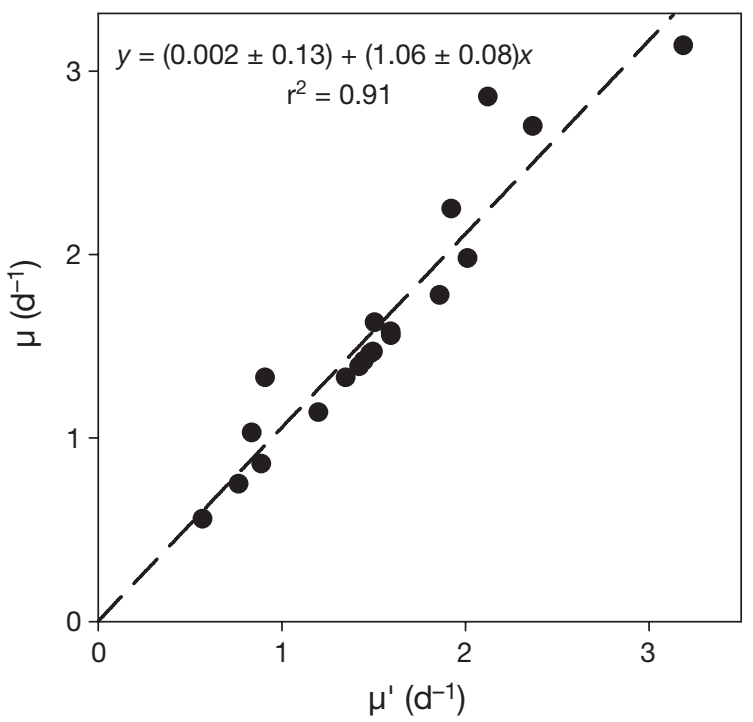

Fig. 6. Relationship between the specific growth rates estimated from the regressions of the linear part in non-linear responses of dilution experiments $(\mu)$ and the specific growth rates estimated considering the final concentration of microzooplankton $\left(\mu^{\prime}\right)$ (see also Fig. 4 \& Table 4) 
maximum clearance rates (Fig. 6). This suggests that estimates of specific growth rates using the linear part of the responses are robust. However, this may not be the rule, and therefore it seems appropriate to increase the number of highly diluted bottles to ensure that these regressions are obtained where processes are more similar to those occurring in a sample without predators (Gallegos 1989). This would avoid the use of the intermediate dilutions, which carry higher uncertainties in meeting the requirements of the method. The specific growth rates thus calculated can be used to estimate the mortality due to microzooplankton in the natural sample (Gallegos 1989, Strom et al. 2001).

Acknowledgements. We thank the members of the Oceanography group at the Instituto de Investigacións Mariñas who participated in the cruises. Special thanks to P. Pazos for help with plankton determinations. We also appreciate the comments of 3 reviewers, which contributed to improving the manuscript. This work was funded by the project REM20000880-C02-01 MAR (Ministerio de Educación y Ciencia) and the project PGIDT01MAR4020PN (Xunta de Galicia). I.G.T. was supported by an FCT (Portuguese Foundation for Science and Technology) doctoral fellowship (SFRH/BD/11309/2002).

\section{LITERATURE CITED}

Agis M, Granda A, Dolan JR (2007) A cautionary note: examples of possible microbial community dynamics in dilution grazing experiments. J Exp Mar Biol Ecol 341:176-183

Álvarez-Salgado XA, Nieto-Cid M, Piedracoba S, Crespo BG and others (2005) Origin and fate of a bloom of Skeletonema costatum during a winter upwelling/downwelling sequence in the Ría de Vigo (NW Spain). J Mar Res 63: $1127-1149$

Andersen T, Schartau AKL, Paasche E (1991) Quantifying external and internal nitrogen and phosphorus pools, as well as nitrogen and phosphorus supplied through remineralization, in coastal marine plankton by means of a dilution technique. Mar Ecol Prog Ser 69:67-80

> Arenovski AL, Lim EL, Caron DA (1995) Mixotrophic nanoplankton in oligotrophic surface waters of the Sargasso Sea may employ phagotrophy to obtain major nutrients. J Plankton Res 17:801-820

Ayukai T (1996) Possible limitation of the dilution technique for estimating growth and grazing mortality rates of picoplanktonic cyanobacteria in oligotrophic tropical waters. J Exp Mar Biol Ecol 198:101-111

Baudoux AC, Noordeloos AAM, Veldhuis MJW, Brussaard CPD (2006) Virally induced mortality of Phaeocystis globosa during two spring blooms in temperate coastal waters. Aquat Microb Ecol 44:207-217

> Bockstahler KR, Coats DW (1993) Spatial and temporal aspects of mixotrophy in Chesapeake Bay dinoflagellates. J Eukaryot Microbiol 40:49-60

Bratbak G, Dundas I (1984) Bacterial dry matter content and biomass estimation. Appl Environ Microbiol 48:755-757

Calbet A, Landry MR (2004) Phytoplankton growth, microzooplankton grazing, and carbon cycling in marine systems. Limnol Oceanogr 49:51-57

Caron DA, Lim EL, Miceli G, Waterbury JB, Valois FW (1991) Grazing and utilization of chroococcoid cyanobacteria and heterotrophic bacteria by protozoa in laboratory cultures and a coastal plankton community. Mar Ecol Prog Ser 76: 205-217

Dolan JR, McKeon K (2004) The reliability of grazing rate estimates from dilution experiments: Have we over-estimated rates of organic carbon consumption? Ocean Sci Discuss $1: 21-36$

Dolan JR, Gallegos CL, Moigis A (2000) Dilution effects on microzooplankton in dilution grazing experiments. Mar Ecol Prog Ser 200:127-139

Elser JJ, Frees DL (1995) Microconsumer grazing and sources of limiting nutrients for phytoplankton growth: application and complications of a nutrient-deletion/dilution-gradient technique. Limnol Oceanogr 40:1-16

Evans C, Archer SD, Jacquet S, Wilson WH (2003) Direct estimates of the contribution of viral lysis and microzooplankton grazing to the decline of a Micromonas spp. population. Aquat Microb Ecol 30:207-219

Figueiras FG, Labarta U, Fernández Reiriz MJ (2002) Coastal upwelling, primary production and mussel growth in the Rías Baixas of Galicia. Hydrobiologia 484:121-131

> Fonda Umani S, Beran A (2003) Seasonal variations in the dynamics of microbial plankton communities: first estimates from experiments in the Gulf of Trieste, Northern Adriatic Sea. Mar Ecol Prog Ser 247:1-16

Frost BW (1972) Effects of size and concentration of food particles on the feeding behavior of the marine copepod Calanus pacificus. Limnol Oceanogr 17:805-815

Gallegos CL (1989) Microzooplankton grazing on phytoplankton in Rhode River, Maryland: nonlinear feeding kinetics. Mar Ecol Prog Ser 57:23-33

> Gaul W, Antia AN, Koeve W (1999) Microzooplankton grazing and nitrogen supply of phytoplankton growth in the temperate and subtropical northeast Atlantic. Mar Ecol Prog Ser 189:93-104

Gifford DJ (1988) Impact of grazing by microzooplankton in the Northwest Arm of Halifax Harbour, Nova Scotia. Mar Ecol Prog Ser 47:249-258

Heinbokel JF (1978) Studies on the functional role of tintinnids in the southern California Bight. I. Grazing and growth rates in laboratory cultures. Mar Biol 47:177-189

Hillebrand H, Dürselen C, Kirschtel D, Pollingher U, Zohary T (1999) Biovolume calculation for pelagic and benthic microalgae. J Phycol 35:403-424

Jeong HJ (1999) The ecological roles of heterotrophic dinoflagellates in marine planktonic community. J Eukaryot Microbiol 46:390-396

John EH, Davidson K (2001) Prey selectivity and the influence of prey carbon:nitrogen ratio on microflagellate grazing. J Exp Mar Biol Ecol 260:93-111

Jürgens K, DeMott WR (1995) Behavioral flexibility in prey selection by bacterivorous nanoflagellates. Limnol Oceanogr 40:1503-1507

Landry MR (1993) Estimating rates of growth and grazing mortality of phytoplankton by the dilution method. In: Kemp PF, Sherr BF, Sherr EB, Cole JJ (eds) Handbook of methods in aquatic microbial ecology. Lewis Publishers, Boca Raton, FL, p 715-722

Landry MR (1994) Methods and controls for measuring the grazing impact of planktonic protists. Mar Microb Food Webs 8:37-57

Landry MR, Hassett RP (1982) Estimating the grazing impact of marine microzooplankton. Mar Biol 67:283-288

Landry MR, Haas LW, Fagerness VL (1984) Dynamics of microbial plankton communities: experiments in Kaneohe Bay, Hawaii. Mar Ecol Prog Ser 16:127-133

Lee S, Fuhrmann JA (1987) Relationships between biovolume and biomass of naturally derived marine bacterioplankton. Appl Environ Microbiol 53:1298-1303 
Lessard EJ, Murrell MC (1998) Microzooplankton herbivory and phytoplankton growth in the northwestern Sargasso Sea. Aquat Microb Ecol 16:173-188

Lessard EJ, Swift E (1986) Dinoflagellates from the North Atlantic classified as phototrophic or heterotrophic by epifluorescence microscopy. J Plankton Res 8:1209-1215

Moigis AG (2006) The clearance rate of microzooplankton as the key element for describing estimated non-linear dilution plots demonstrated by a model. Mar Biol 149:743-762

Porter KG, Feig YS (1980) The use of DAPI for identifying and counting aquatic microflora. Limnol Oceanogr 25:943-948

Putt M, Stoecker DK (1989) An experimental determined carbon:volume ratio for marine 'oligotrichous' ciliates from estuarine and coastal waters. Limnol Oceanogr 34: 1097-1103

Rassoulzadegan F, Sheldon RW (1986) Predator-prey interactions of nanozooplankton and bacteria in an oligotrophic marine environment. Limnol Oceanogr 31:1010-1021

Rodríguez F, Pazos Y, Maneiro J, Zapata M (2003) Temporal variation in phytoplankton assemblages and pigment composition at a fixed station of the Ría of Pontevedra. Estuar Coast Shelf Sci 58:499-515

Sanders RW, Porter KG, Caron DA (1990) Relationship between phototrophy and phagotrophy in the mixotrophic chrysophyte Poterioochromonas malhamensis. Microb Ecol 19:97-109

Sime-Ngando T, Pradeep Ram AS (2005) Grazer effects on prokaryotes and viruses in a freshwater microcosm experiment. Aquat Microb Ecol 41:115-124

Šimek K, Pernthaler J, Weinbauer MG, Hornák K and others (2001) Changes in bacterial community composition and dynamics and viral mortality rates associated with enhanced flagellate grazing in a mesoeutrophic reservoir. Appl Environ Microbiol 67:2723-2733

Stoecker DK (1999) Mixotrophy among dinoflagellates.

Editorial responsibility: Klaus Jürgens,

Rostock, Germany
J Eukaryot Microbiol 46:397-401

Strathmann R (1967) Estimating the organic carbon content of phytoplankton from cell volume or plasma volume. Limnol Oceanogr 12:411-418

Strom SL, Brainard MA, Holmes JL, Olson MB (2001) Phytoplankton blooms are strongly impacted by microzooplankton grazing in coastal North Pacific waters. Mar Biol 138: 355-368

Tremaine SC, Mills AL (1987) Tests of the critical assumptions of the dilution method for estimating bacterivory by microeucaryotes. Appl Environ Microbiol 53:2914-2921

Verity PG (1991) Feeding in planktonic protozoans: evidence for non-random acquisition of prey. J Protozool 38:69-76

Verity PG, Robertson CY, Tronzo CR, Andrews MG, Nelson JR, Sieracki ME (1992) Relationships between cell volume and the carbon and nitrogen content of marine photosynthetic nanoplankton. Limnol Oceanogr 37:1434-1446

Weinbauer MG, Hornák K, Jezbera J, Nedoma J, Dolan JR, Šimek K (2007) Synergistic and antagonistic effects of viral lysis and protistan grazing on bacterial biomass, production and diversity. Environ Microbiol 9:777-788

Wheeler PA, Kirchman DL (1986) Utilization of inorganic and organic nitrogen by bacteria in marine systems. Limnol Oceanogr 31:998-1009

> Wolfe GV, Steinke M, Kirst GO (1997) Grazing-activated chemical defence in a unicellular marine alga. Nature 387 : 894-897

Worden AZ, Binder BJ (2003) Application of dilution experiments for measuring growth and mortality rates among Prochlorococcus and Synechococcus populations in oligotrophic environments. Aquat Microb Ecol 30:159-174

Zubkov MV, Tarran GA (2008) High bacterivory by the smallest phytoplankton in the North Atlantic Ocean. Nature 455:224-226

Submitted: May 13, 2008; Accepted: January 6, 2009 Proofs received from author(s): March 17, 2009 